\title{
STAN BRAKHAGE, NÄKYJEN KULJETTAJA
}

\begin{abstract}
Nykyelokuvan tunnetuimpiin kuuluvalla amerikkalaisella elokuvantekijällä ja-ajattelijalla, Stan Brakhagella (syntymänimeltään Robert Sanders), oli kuollessaan 70-vuotiaana maaliskuussa vuonna 2003 noin viidenkymmenen työteliään vuoden ja lähes neljänsadan elokuvan tuotanto takanaan. Elokuvista lyhimmät ovat alle kymmenen sekunnin mittaisia, mutta pisimmät vastaavasti yltävät yli neljään tuntiin. Laajan ja moniaineksisen tuotannon pysyväksi tavoitteeksi muodostui jo varhain pyrkimys taltioida ihmissilmän rajatonta kykyä nähdä ilmeisen tuolle puolen.
\end{abstract}

Stan Brakhage (1933-2003) jatkaa sitä avantgarde-elokuvan amerikkalaista perinnettä, johon hänen edeltäjinään ja osin myös aikalaisinaan lukeutuivat muun muassa Maya Deren, Marie Menken ja Sidney Peterson. Heidän tuotannostaan hän on itse myös kirjoittanut (ks. Brakhage 1989). Tuon perinteen voi halutessaan määritellä P. Adams Sitneyn (1979) tavoin alkaneen Maya Derenin elokuvasta Meshes of the Afternoon (1943). Mutta tietysti tällaiset tarkat ajalliset määrittelyt ovat aina likiarvoja ja parhaimmillaankin vasta suuntaa antavia.

Brakhagen vuonna 1952 Interim-elokuvalla alkaneen tuotannon osalta yhtenä käännekohtana voidaan pitää vuonna 1961 valmistunutta 20-minuuttista Preludeelokuvaa, jonka tekijä sittemmin liitti laajemman Dog Star Man -elokuvansa (1964) johdannoksi. Siitä puolestaan tuli jo 1960-luvulla yksi kokeellisen elokuvan keskeisistä klassikoista. Brakhagen elokuva-ajattelun kulmakivi, Metaphors on Vision (vapaasti suomennettuna "Näyn kuljetuksia"), valmistui suurelta osin samoina vuosina 1950- ja 60-lukujen taitteessa. ${ }^{1}$

Sen lisäksi, että sekä Dog Star Man että Metaphors on Vision paikantuvat tärkeään kohtaan tekijänsä omassa tuotannossa, ne ajoittuvat olennaiseen saumakohtaan amerikkalaisen kokeellisen elokuvan perinteessä ylipäätään. Juuri noihin aikoihin 1960-luvun alussa oltiin siirtymässä "avantgardesta undergroundiin" ja siitä edelleen myöhemmin 1970-luvun taitteen tuntumassa "laajennettuun elokuvaan". Gene Youngbloodin (1970) teos Expanded Cinema on näiden muutoskohtien yhteen kokoava kronikka. Kenties jotenkin oireellisena voisi pitää sitäkin, että aiemman muutoskohdan molemmat termit - avantgarde ja underground - ovat tavoillaan

\footnotetext{
1 Anthology Film Archives ja Light Industry ovat julkaisseet tämän teoksen uudelleen, nyt yksissä kansissa sekä alkuperäisen näköispainoksena että P. Adams Sitneyn kommenttien kera (ks. Brakhage 2017). Verkosta sama löytyy myös alkuperäisestä Film Culture -lehdestä skannattuna kopiona (https://monoskop.org/images/d/de/Brakhage_Stan_Metaphors_on_Vision.pdf ). Brakhagen tuotannon kattava filmografia löytyy puolestaan Wikipediasta: https://en.wikipedia.org/wiki/Stan_Brakhage_filmography.
} 
sotilaallisia, edellinen etujoukon pioneeri- ja jälkimmäinen maanalaisen armeijan hengessä. Kummassakin tapauksessa on mahdollista kysyä, minkä puolesta ja/ tai mitä vastaan ne liikkeinä oikeastaan taistelivat? Vastaukset riippuvat kuitenkin paljolti siitä, kenen elokuvantekijän näkökulmasta asetelmaa tarkastellaan.

Elokuvan osalta laajempi kokeilevuuden perinne alkoi aivan uudella tavalla kukoistaa 1960-luvun alusta lähtien. Toiminnan tarpeisiin Yhdysvalloissa ilmestyi oma julkaisu, Film Culture -lehti. Sen oli perustanut koko perinteen kannalta kenties keskeisin yksittäinen vaikuttaja, Liettuasta sotavuosien jälkeen Yhdysvaltoihin emigroitunut Jonas Mekas jo vuonna 1955. Toinen merkittävä tapahtuma oli The Filmmakers' Cooperative -kollektiivin perustaminen niin ikään Mekasin aloitteesta alkuvuodesta 1962.

Kollektiivin keskeisin toimintamuoto olivat säännölliset kokeellisten elokuvien esitystapahtumat ja niihin liittyvät keskustelutilaisuudet. Tältä pohjalta Mekas perusti Anthology Film Archives -instituutin vuonna 1970. Se esittää, arkistoi ja digitoi kokeellisen elokuvan piiriin kuuluvaa aineistoa yhä edelleen. Toisen merkittävän tuotanto- ja esitysympäristön, Millennium Film Workshopin, perusti Howard Guttenplan New Yorkissa vuonna 1966. Sen julkaisemasta ja edelleen (nykyisin kaksi kertaa vuodessa) ilmestyvästä Millennium Film Journal -lehdestä tuli nopeasti Film Culture -lehden lisäksi kokeellisen elokuvan "näyteikkuna".

Sekä elokuvia että tämäntyyppistä toimintaa yleisemminkin kuvaamaan muodostui jo varhain 1960-luvulla käsite "Uusi amerikkalainen elokuva". Sitneyn (1979, viii) mukaan se korvasi aiemmin käytössä olleet "elokuvarunot" ja "eksperimentaaliset elokuvat" -määritelmät. Kokeellisen elokuvan ilosanoman laajalle levinneessä hengessä uuden amerikkalaisen elokuvan nimiin koottuja esityssarjoja kierrätettiin ympäri maailman, sittemmin myös Helsingissä vuonna 1968. Aihepiiriä esittelevää kirjallisuutta alkoi ilmestyä. Gregory Battcock toimitti kokoelman haastatteluja ja muita kirjoituksia nimellä The New American Cinema (1967); Sheldon Renan julkaisi kattavan katsauksen An Introduction to the American Underground Film (1967); Parker Tyler kokosi yhteen aiempia esseitään otsikolla Underground Film; A Critical History (1969). Kaikissa vastaavissa teoksissa Stan Brakhage on uuden amerikkalaisen elokuvan keskeinen nimi. Eikä kiinnostus jäänyt pelkästään Yhdysvaltoihin. Esimerkkeinä ranskalaisesta mielenkiinnosta ilmiötä kohtaan voisivat olla Noël Burchin teos Praxis du cinéma (1969) ja Louis Marcorelles'in Éléments pour un nouveau cinéma (1970), joihin molempiin esimerkiksi Gilles Deleuze viittaa kirjoittaessaan (tosin vain ohimennen) Brakhagesta Cinéma-teoksissaan (Deleuze 1986, 84, 230; 1989, 200, 316).

Kun Stephen Dwoskin julkaisi kokeellisessa perinteessä 1960-luvulla tapahtunutta maailmanlaajuista leviämistä koskevan katsauksensa vuonna 1975 otsikolla Film Is, hän nimesi käsittelemänsä elokuvamuodon osuvasti termillä "kansainvälinen vapaa elokuva". Kärjistäen voisi siis väittää, että se mitä globaalissa elokuvakulttuurissa 1960-luvun alussa tapahtui, oli elokuvan vapautuminen paitsi ilmaisullisista ja tuotannollis-kaupallisista myös kansallisista kahleista. Stan Brakhagen elokuvat nähtiin 1960-luvun alussa tällaisen vapautumisen ilmentyminä ja niiden tekijä vastaavasti tuon asenteen ruumiillistumana.

\section{Näkijän silmä}

Ajateltaessa amerikkalaista elokuvakulttuuria laajemmin studiokauden Hollywoodia ei oikeastaan enää ollut olemassa 1960-luvun alussa. Toisaalta myöskään "uusi Hollywood" ei ollut vielä muotoutunut. Yksi underground-elokuvan keskeisiä hahmoja, Andy Warhol, totesikin, että 1960-luvun alussa Hollywood oli kiinnostavimmillaan juuri siksi, ettei siellä tapahtunut yhtään mitään, "ei enää eikä vielä". David E. 
James (2005) on vertaillut Brakhagen ja Warholin erilaisia pyrkimyksiä Hollywoodin suhteen: edellinen torjui sen, kun jälkimmäinen sitä vastoin pyrki yhteistyöhön sen kanssa. Vanhan studiokauden hiipumisen ja uuden underground-elokuvan vahvistumisen ohella samaan ajankohtaan on mahdollista sijoittaa vielä niiden jonkinlainen "välimuotokin", amerikkalaisen indie-elokuvan vahvistunut näkyvyys, esimerkkinä John Cassavetesin kaksi ensimmäistä elokuvaa, Varjoja (Shadows 1959) ja Hämärän lapset (Too Late Blues 1961).

Kokeellisen "anti-Hollywood"-perinteen toistaiseksi merkittävin kronikoitsija ja historioitsija P. Adams Sitney on teoksessaan Visionary Film (alk. 1974) ryhmitellyt sotien jälkeisen pohjoisamerikkalaisen avantgarden viiteen suuntaukseen: transsielokuvaan (trance film: Maya Deren), lyyriseen elokuvaan (lyric film: Brakhage 1950-luvulla), my topoeettiseen elokuvaan (mythopoieic film: Brakhage 1960-luvulla), strukturaaliseen elokuvaan (structural film: Michael Snow) ja osallistuvaan elokuvaan (participatory film: George Landow). Sitneyn historiikin kanonistinen asema, niin hyvässä kuin pahassa, on tunnustettu tosiasia, samoin kuin se, että tuon tarinan kenties keskeisin yksittäinen hahmo on juuri Stan Brakhage.

Sen enempää ajalliset kuin tekijäkohtaisetkaan rajat Sitneyn määrittelemien suuntausten välillä eivät tietenkään ole ehdottomia. Lisäksi joitakin merkittäviä tekijöitä (kuten Hollis Frampton, Harry Smith tai jopa Michael Snow) on varsin hankala sijoittaa mihinkään yhteen luokitukseen. Sitneyn jaottelu olkoon tässä kuitenkin esimerkkinä siitä, että tuo noin kolmenkymmenen vuoden kokeellinen perinne 1940-luvulta 1970-luvulle ei ollut millään tavalla yhtenäinen huolimatta siitä, että yhtenäistäviksi nimityksiksi voitiin määritellä niin kokeellisuuden kuin uudenkin käsitteet.

Juuri Brakhagen kohdalla Sitney on kuitenkin tiukasti pitänyt kiinni tulkinnasta, jonka mukaan perinteen moniin muihin tekijöihin verrattuna nimenomaan hän edustaa romanttista ja modernistista taiteilijakäsitystä puhtaimmillaan. Tämän käsityksen pysyvyydestä kertoo esimerkiksi se, että kirjoittaessaan Brakhagen "runousopista" suhteellisen tuoreessa teoksessaan The Cinema of Poetry Sitney (2015, 149 passim.) edelleen määrittelee tekijän tuotannolle kolme kronologista ulottuvuutta: 1950-luvun kriisilyriikka (crisis lyric), 1960- ja 70-lukujen mytopoeettiset sarjaelokuvat (mythopoeic serial film) ja 1980-luvulla alkaneet kuvagnostiset tutkielmat (imagnostic films). Tällaiselle tekijälle käsitteet runous ja runoilija ovat lähtökohtaisesti ja aina voimakkaan positiivisesti arvoladattuja. Runoilija on ennen muuta Näkijä, Visionääri, ja Sitneylle juuri Brakhage on tällaisen käsityksen aidoin edustaja. Hieman toisenlaisen tulkinnan on tehnyt David E. James (2005), jolle keskeinen epiteetti Brakhagelle kylläkin saattaisi olla "runoilija", mutta kenties enemmän barokki-musiikin ja Johann Sebastian Bachin kuin Charles Olsonin edustaman uusromantiikan tai T. S. Eliotin ja modernismin hengessä.

Luonnehdinta Näkijäksi isolla N:llä tai Visionääriksi isolla V:llä on elänyt pitkään, ja oikeastaan vasta Brakhagen uran viime vuosina tällaista kanonisointia on alettu myös kritisoida. Samalla hänen tuotantoaan on opittu katsomaan hieman toisin. Esimerkiksi William C. Wees (1992) on pohtinut Brakhagen tuotannon merkitystä kognition näkökulmasta ja David E. James (1989) sellaisen materialismin kannalta, jossa voi nähdä myös selkeitä poliittisia pyrkimyksiä. Ara Osterweil taas on nähnyt teoksessaan Flesh Cinema (2014) Brakhagen elokuvissa erityisen vahvoja ruumiillisuuden kuvauksia. Ehkä yksi osa-alueista, joka tuntuisi edelleen odottavan kattavampaa tarkastelua on Brakhagen huumori, siten kuin se pilkahtaa usein odottamatta esiin itse elokuvissa ja siten kuin se käy ilmi hänen kirjoituksissaan esimerkiksi toistuvina sanaleikkeinä:

[-] and would I do better to say 'zen,' moan 'A,' pursue the water-lilies spreading

Pollock in the air and follow thru the process to 'deK'?, or would a sound ring 
influenzing describe a film more filmically than script, than art, than arc-key, than spiri-spherically?; and is a film, a fil, a fi-fie-foe-fiddle-di-dum?" (Brakhage 2017, 160.)

\section{Ympyrän kehällä}

1960-luvun alussa Brakhagesta siis tuli äärimmäisen subjektiivisen elokuvantekijän perustyyppi, jopa sellaisen ruumiillistuma ja symboli. Lausunnoillaan, haastatteluillaan ja kirjoituksillaan Brakhage itse myös auliisti ruokki tällaista käsitystä. Kenties niitäkin enemmän sen vahvuuteen vaikutti paitsi Brakhagen henkilökohtainen elämä myös sellainen toistuva korostus, jonka mukaan elämä ja elokuva nimenomaan hänen tapauksessaan olivat lähtemättömästi toisiinsa kietoutuneita. Vuonna 1957 Brakhage paitsi avioitui myös muutti perheineen hirsikämppään lähes asumattomille seuduille Coloradon vuorille, missä hän enemmän tai vähemmän pysyvästi sitten asusteli aina vuosituhannen loppuun asti. Keskeinen osa Brakahgen elokuvatuotannosta on siis tuollaisen, hyvin läheisesti luontoon sekä perhearkeen sitoutuneen, välittömästi käsillä olevan ympäristön tuotetta. Toinen alueelle kytkenyt yhteys oli aina 1980-luvun alkuun jatkunut tuntiopettajan pesti Coloradon yliopistossa Boulderissa. Brakhage ei kuitenkaan luennoinut elokuvien tekemisestä vaan elokuvan historiasta.

Tunnetusti Brakhage kreditoi elokuvansa jo 1950-luvulla muotoon "By Brakhage". Tällä hän tarkoitti sitä, että kreditoitu "Brakhage" on ikään kuin tavaramerkki. Se ei ole yksin hän itse, vaan koko hänen perheensä ja ympäröivä yhteisö mukaan lukien kotieläimet, kodin elinpiiri ja jopa se lukemattomien suojelusenkelien ja henkiolentojen joukko, joka näkymättömän läsnäolonsa muodossa yhtä kaikki vaikutti myös näkyvän ja tällä tavalla esimerkiksi elokuvan keinoin taltioitavissa olevan ilmiömaailman luonteeseen. Tätä ympäristöä Brakhage kutsui muusakseen.

Tavallaan tällaista asennetta voi hyvin pitää kokeellisen elokuvailmaisun perinteessä tyypillisen paradoksaalisena ilmiönä. Siinä tekijä yhtäältä pyrkii olemaan äärimmäisen omaehtoinen ja itsenäinen taiteilija, joka määrää sen, millaisia elokuvat valmistuttuaan lopulta ovat. Omat elokuvansa tällainen tekijä suunnittelee, kirjoittaa, kuvaa, leikkaa, ohjaa, tuottaa ja usein myös itse "näyttelee" niissä sekä käy esittämässä niitä ja puhumassa niistä. Toisaalta - ja tämä on asetelman paradoksaalinen piirre - hän selittää pyrkivänsä häivyttämään itsensä niin tehokkaasti kuin mahdollista, jotta jokin suurempi, kätketympi ja salaisempi voisi tulla näkyviin hänen töissään. Brakhage itse tuon tuosta korosti omaa "vain välineellistä" rooliaan. Toinen aikalaistekijä kokeellisen elokuvan piirissä, Harry Smith, meni jopa niin pitkälle, että väitti elokuviensa varsinaiseksi tekijäksi Jumalaa siinä missä hän itse oli niiden toteutuksessa vain tahdoton välikappale.

Uutta valoa Brakhagen tuotantoon ja ajatteluun on tuonut Brakhagen ensimmäisen puolison, Jane Wodeningin teos Brakhage's Childhood (2015), joka haastattelujen kautta kronikoi tekijän ensimmäiset elinvuodet 1930-luvulla ja 1940-luvun sotavuosina noin kahteentoista ikävuoteen asti. Teoksen jälkisanoissa Tony Pipolo pohtii sitä, millä perusteilla tekijä on antanut jonkun toisen kirjoittaa "omaelämäkertansa". Kenties tekijä on tällä tavalla halunnut säilyttää itsellään mahdollisuuden sanoutua kertomuksesta tarpeen tullen irti; koska sehän ei ollut "itse tehty". Samantyyppisen irti sanoutumisen ja itse tehdyn välisen ristipaineen voi tunnistaa monista ajatuksista ja toteutuksista, jotka Brakhage liittää elokuviinsa. Asetelman voi kuvailla jänneväliksi, jonka toisessa päässä on idea sulautumisesta kokonaan jonkin toisen - tai ilmaisun itsensä - sisään ja vastaavasti toisessa päässä on idea kokonaisesta, eheästä ja ennen kaikkea itseriittoisesta taiteilija-minästä.

Brakhagen elokuvat ovat kokeellisen elokuvaperinteen vanhempien esimerkkien mukaisesti vahvasti omaelämäkerrallisia, niissä olioistuu hyvin henkilökohtainen 
suhde elokuvaan ja taiteeseen ylipäätään. Tavallaan jo Dog Star Man on omaelämäkerrallinen "kertomus" Coloradon lumisista metsistä, missä mies kiipeää ylös vuorenrinnettä koira seuranaan, kaataa puun ja pilkkoo sen. Ilmaisunsa takia yksinkertaisesta tapahtumasta kuitenkin tulee "allegoria", jollaista David E. Jamesin (1989) tapaan voi toki pitää tyypillisenä asetelmana 1960-luvun amerikkalaiselle kokeelliselle elokuvalle yleisemminkin. Kyse voisi olla vertauskuvallisesta tarinasta, joka käsittelee ihmisen osaa asukkina jossakin tarkemmin määrittelemättömässä paikassa Maa-planeetan pinnalla. Puu on "maailmanpuu", ja mies edustaa sen tuhoavaa ihmistä. Tällä planeetalla elämä kaikkineen on hyvin yksinkertaisesti viime kädessä vain auringosta ja sen valosta riippuvainen asia. Usein toistamansa ajatuksen Brakhage sijoittaa varhaiskeskiajalla eläneen, irlantilaisen teologin, Johannes Scotus Eriugenan nimiin: "Kaikki mitä on olemassa, on valoa" (Ganguly 2017, 45, 56).

Elokuvantekijän asenne ei paljoa myöhemminkään laimentunut, jos kohta siihen aivan ilmeisesti tuli aiempaa enemmän itseironiaa. Esimerkiksi 1990-luvulla Brakhage yritti vakuuttaa, että elokuvien teossa tärkein lähtökohta on oikean nukkumisasennon löytäminen. Itseironisuutensa ohella kommentissa on kuitenkin myös "totta toinen puoli", sillä jo varhain - ja tästä tavoitteesta Dog Star Man saattaisi olla yksi ensimmäisiä johdonmukaisia esimerkkejä - Brakhage on puhunut elokuvan "hypnagogisesta" ulottuvuudesta, yrityksestä tallentaa filmille ei enää valveilla mutta ei vielä täysin unessakaan olemisen visuaalinen kokemus. Siis ikään kuin "dokumentoida" elokuviin valvetilan ja sikeän unen välisessä puoliunessa tapahtuvia näköhavaintoja:

Todellakin ajattelen, että elokuvani ovat dokumentaarisia. Ne ovat minun yritykseni taltioida näkemisen tapahtuma niin tarkkana esityksenä kuin mahdollista. En koskaan kehittele fantasioita enkä koskaan ole keksinyt jotakin vain siksi, että se kuvana näyttäisi mielenkiintoiselta. Kamppailen kovasti päästäkseni elokuvan keinoin niin täydelliseen vastaavuuteen kuin mahdollista suhteessa siihen, miten itse näen ympäröivän todellisuuden. (Brakhage teoksessa Wees 1992, 79.)

Brakhage piti erityisen osuvana myös sitä, että hänen sairastuttuaan 1990-luvun lopulla syöpään lääkärit epäilivät ohjaajan käyttämien myrkyllisten väriaineiden vaikuttaneen ratkaisevasti taudin puhkeamiseen. Näin eivät ainoastaan hänen elokuviensa toistuvat aiheet - syntymä, elämä ja kuolema - vaan myös niihin kytkeytyvät elokuvalliset aineet (kuten värien sisältämät myrkylliset ainesosat kuoleman vauhdittajina) kietoutuivat lähtemättömästi Brakhagen elokuva-elämän kokonaisrakennelmaan. Tekijä, jolle elokuvan ja elämän välillä ei ollut laadullista eroa, saattoi siis kokea olevansa iloinen siitä, että juuri elokuva tavallaan tappoi hänet. "Todisteena" asenteesta voisi pitää vaikkapa Brakhagen viimeiseksi jäänyttä elokuvaa Chinese Series (2003), jonka hän teki kuolinvuoteellaan raapimalla mustaa $35 \mathrm{~mm}: n$ filminauhaa terävillä kynsillään.

P. Adams Sitneyn tapaan tällaisen asennon ja asenteen taustassa voi helposti (ja varmaan ainakin osittain myös oikeutetusti) nähdä romanttisen ja idealistisen runoilijaihanteen. Taiteilija elää taiteelleen ja taiteestaan, aineellisesti välillä hyvin niukoinkin resurssein ja se, mitä hän tekee, liittyy ensi sijassa aina kiinteästi tuon taiteen perusolemukseen. Brakhagen kohdalla se on näkemisen, vision mahdollisuuksien ja ominaisuuksien tutkimista, kartoitusta, löytämistä ja muuntelua. Tällaisen estetiikan merkkipaaluja ovat elokuva Dog Star Man ja saman aineiston pohjalta koottu laajempi versio The Art of Vision (1964) sekä Film Culture -lehdessä vuonna 1963 ilmestynyt laaja essee Metaphors on Vision, jonka alkua on usein siteerattu ikään kuin Brakhagen "mytopoeettisen" kauden aatteellisena manifestina: 
Kuvittele silmää, jota eivät ohjaile ihmisen tekemät perspektiivin lainalaisuudet; silmää, jolla ei ole kompositioon liittyviä ennakkokäsityksiä; silmää, joka ei vastaa kaiken nimeen vaan voi tuntea jokaisen elämässä kohdatun objektin havaitsemista koskevana seikkailuna. Kuinka monta väriä onkaan olemassa ruohikossa ryömivälle lapselle, joka ei vielä tiedä, mitä sana 'vihreä' tarkoittaa? Kuinka monta sateenkaarta voi valo tuoda harjaantumattomaan silmään? Miten pitkälle silmä voi olla tietoinen lämpöaalloissa tapahtuville muutoksille? Kuvittele maailma, jossa käsittämättömät objektit elävät ja jossa värisevät liikkeen loputtomat muunnelmat ja lukemattomat värien vivahteet.

Kuvittele maailma ennen kuin siitä tuli 'ja alussa oli sana'. (Brakhage 2017, isn.)

Avantgarde on aina ollut vahvasti poikkitaiteellinen ilmiö, ja kokeellisen elokuvan näkökulmasta yhteys eritoten kuvataiteisiin ja runouteen on ollut perinteenä vahva. Myös Brakhagen kohdalla 16-vuotiaana tapahtunut tutustuminen Ezra Poundin The Cantos -projektiin (alk. 1915) oli käänteentekevä kokemus. Poundin lisäksi Brakhage tuon tuosta viittaa Gertrude Steiniin, jonka kuuluisaa säettä "A rose is a rose is a rose" voisi pitää jopa eräänlaisena Brakhage-mandalana, esiintyyhän se jo niin 1960-luvun alun teksteissä kuin myöhäisessä esseessä vielä 1990-luvullakin:

Kuvion olennaiset piirteet, kuten ympyrä, kiertokulku, toisto, pelkistys, itseensä viittaavuus ja niin edelleen, ovat ominaisuuksia, joiden olemassaolo on helppo havaita myös Brakhagen elokuvatuotannosta.

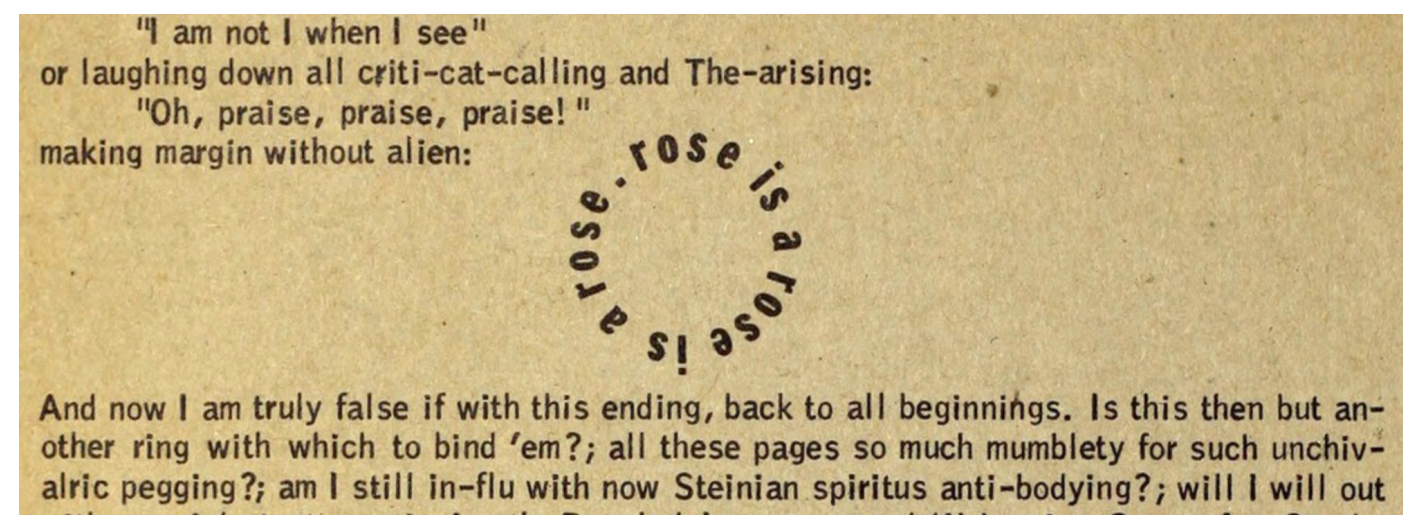

When she seems to simply name (or noun), over and over again, the puns take over emphatically:

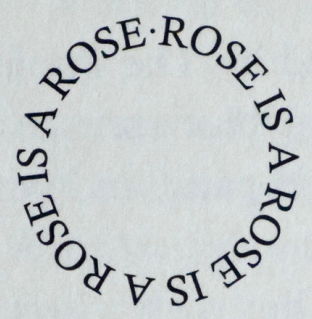

The clarity of the poem suggests full-face-shape of the flower, the syllables the petals.

The "o"s rhyme this shape in sound, the sisses the three sisters of Fate: Birth, Sex, Death.

Ylempi: Metaphors on Vision (1963); alempi tekstistä "Gertrude Stein: Meditative literature and film" (1990, teoksessa Brakhage 2001, 196). 
Kenties luonnehdinnat romantikoksi ja runoilijaksi ovat sittenkin vain yleistykseen tähtäävä tulkinta, eräänlainen tieten tahtoen tarjoiltu julkinen kuva, jonka suojissa tekijän on ollut mahdollista tehdä omaehtoisia tutkimuksiaan turvallisissa oloissa. Enemmän kuin päättymätön kamppailu Egon pakkopaidan ja utopistisen minättömyyden kesken, Brakhagen tutkimuksia innoittava jänneväli saattaa sittenkin olla hyvin yksinkertaisesti pyrkimys tavoittaa immanentin luminenssin moniulotteisuus, tämänhetkisyyden - peräti 'tämäisyyden' (haecceity Duns Scotuksen ja Gilles Deleuzen käsitteistössä) - ilmaisullinen voima ja kyky antautua sen vallan vietäväksi.

\section{Valon kieli}

Vaikka suuri osa Brakhagen tuotannosta on "mykkäelokuvia", runouden ohella musiikin perinne muodostui jo varhain tärkeäksi nimenomaan mallin ja muodon antajana. Brakhagelle klassisen musiikin mestari on Bach, mutta musiikki tarjosi myös lineaarisen kerronnan vaihtoehtoja. Brakhage kiinnostui etenkin John Cagen ja Edgar Varesen älyllisestä minimalismista - ja teki Cagen kanssa myös yhteistyötä. Toisen aikalaissäveltäjän, James Tenneyn (jonka musiikkia Brakhage on käyttänytkin muutamissa elokuvissaan) opastamana hän tutustui elektronisen musiikin salaisuuksiin jo 1950-luvun lopulla. Brakhagen elokuvallisissa kokeiluissa liike, väri ja valo pyrkivät muuttumaan musiikiksi katsojan tajunnassa. Vastaavan tavoitteen tunnistaa jo 1920-luvun ranskalaisen, kokeellisen elokuvan piirissä eritoten Germaine Dulacin tuotannossa. Valkokankaalle heijastettujen äänettömien kuvien ajateltiin tuottavan kuviteltua musiikkia katsojien mielissä. Toisen aistinalueen (näkö) ärsykkeet synnyttivät reaktioita toisen (kuulo) alueella. Samassa hengessä Brakhage tutki, miten kuuleminen itsessään operoi tuossa "lihaikkunassa".

Silmää ei kuitenkaan enää ajateltu vain näkökyvyn orgaanisena välineenä eli pelkän aistimusimpulssin välittäjänä, vaan ennen muuta itsenäisesti ajattelevana elimenä, kenties jopa olentona, jolla oli oma tahto, mieli ja kyky ajatella. Tuon kuvitellun silmä-olion kykyä ajatella ei ainoastaan ollut mahdollista vaan sitä myös piti kehittää. Juuri tähän tarkoitukseen elokuva tarjosi monia välineitä ja käyttötapoja. Ensinnäkin silmä-oliota tuli kouluttaa oppimaan pois totutuista ja tavanomaisista sekä pahimmillaan turmelevista näkötavoista. Toisekseen sitä oli harjaannutettava näkyvän todellisuuden vielä näkymättömien osa-alueiden havaitsemisessa.

Brakhagen elokuville tyypillisesti toistuva lähtökohta on usein myös kuvan ja kielen välisen suhteen pohdiskelu. Sana saa kuvan kaltaisen aseman ja merkityksen siinä prosessissa, joka ei enää kätke omia puutteitaan esittävyyteensä, vaan pyrkii tavoittamaan suoraan sen, miten ajattelu, mieli, tajunta ja havainto operoivat. Taaskaan kieltä ei niinkään ajatella johonkin viittaavana, jotakin ilmaisevana ja esittävänä välineenä, vaan silmän lailla jollakin tavalla autonomisena ja itseensä viittaavana, refleksiivisenä "olentona". Tällaisen sanojen käytön voi lukea Brakhagen kirjoituksista ja tavasta, jolla kielen sanat ovat konkreettisesti Brakhagen elokuvissa. Hän raaputtaa - siis tavallaan kirjoittaa - ne suoraan filminauhan pintaan. Samalla tavalla etenkin myöhäistuotannossaan hän täytti koko kuvaruudun, kirjoittamalla, piirtämällä ja maalaamalla siihen suoraan käyttämättä kameraa.

Ilmaisun kärki on suunnattu tältä perustalta niihin tunteisiin, joita mielen prosesseja rekonstruoivat kuvasarjat oletetusti puristavat esiin. Brakhagen ajattelu, tapahtuipa se kirjoitetun kielen tai itsensä "elokuvan kielen" keinoin, on muunnelma niistä periaatteista, joita esimerkiksi Jean Epstein jo 1920-luvulla kutsui käsitteellä lyrosofia - tunteen ja ajattelun saumaton dialogi. Brakhage itse puolestaan piti elokuvataiteen suurimpana mestarina Sergei Eisensteiniä, josta kirjoitti innoittuneen asiantuntevasti Film Biographies -teoksessaan (alk. 1977) Charlie Chaplinin, Fritz 
Langin ja monen muun ohella. Runoilijan urasta haaveillut Brakhage itse kuitenkin hakeutui elokuvan pariin Jean Cocteaun Orfeus-elokuvien innoittamana.

Brakhagen elokuvissa henkilökohtainen kuvasto saa muodokseen tarkkaan hahmotellun ja järjestetyn rakenteen, jossa tekijän ja kameran ohella entisestään korostuu leikkauksen keskeinen merkitys. Eikä siinä enää tarvita ääntä, sillä kuten todettu, se syntyy kuvista ja niiden liikkeestä suoraan katsojan (toivottavasti aktivoituneessa) tajunnassa. Dog Star Man on monessa suhteessa tämän periaatteen jalostunut luomus. Elokuva on käännekohdassa myös kontekstinsa osalta, sillä kokeellisen amerikkalaisen elokuvan (sekä Brakhagen) varhaisemman tuotannon kannalta keskeisin esityspaikka oli ollut Amos Vogelin omistama "Cinema 16" New Yorkissa, mutta Preludesta (1961) alkoi uusi yhteistyö Jonas Mekasin pyörittämän, tuolloin vasta perustetun The Filmmakers' Cooperative'n kanssa.

Dog Star Man -kokonaisuuden muut neljä osaa rakentuvat tietyn logiikan varaan: johdannon jälkeinen A-osa sellaisenaan, mutta B-osa A:n ja yhden uuden, C-osa A:n ja B:n sekä yhden uuden ja viimeinen D-osa A:n, B:n, C:n sekä yhden uuden tason päällekkäisvalotuksina. Myöhäisempi ja laajempi versio, The Art of Vision sitten purkaa nämä päällekkäisyydet peräkkäisyydeksi antaen tällä tavalla mahdollisuuden tarkastella yksityiskohtaisemmin sitä, millaisista elementeistä aiempi kokonaisuus koostui. Uhkaava, ympäröivä maailma ei enää katso tekijää, kuten Stephen Dwoskinin $(1985,149-151)$ mukaan vielä Brakhagen aiemmassa tuotannossa oli tapana. Dog Star Manin myötä tekijä alkaa katsoa maailmaa ympärillään sekä entistä tarkemmin että entistä tiukemmin pohtien tuon katsomisen itsensä luonnetta ja mahdollisuuksia.

Aiemmissa elokuvissa (esimerkiksi Window Water Baby Moving [1959]), Brakhage tutkii maailman luoduksi tulemista konkreettisella tavalla oman lapsensa syntymän kautta. The Dead -elokuvan (1960) myötä tuo maailma olennaisesti laajenee koskemaan myös oman aikakauden Eurooppaa. Yksi seuraavista töistä Dog Star Man -vaiheen jälkeen, Mothlight (1964), on sekin omanlaisensa merkkipaalu tekijän tuotannossa: elokuva on toteutettu periaatteessa kokonaan ilman kameraa siten, että läpinäkyvään teippinauhaan on liimattu erilaisia luonnosta peräisin olevia asioita (kuten yöperhosia ja niiden siipiä) ja tämä "teippi-elokuva" on sitten kiinnitetty kirkkaaseen 16 mm:n filminauhaan, jota itsessään on myös muutoin käsitelty raapimalla, syövyttämällä, värjäämällä, ja niin edelleen. Myös tässä tapauksessa olosuhteet määrittelivät lopputulosta. Brakhage "joutui" tekemään tällaisen elokuvan koska häneltä oli varastettu 16 mm:n kamera, eikä uutta ollut varaa hankkia.

Näkemisen, havaitsemisen, vision mahdollisuuksia Brakhage on tarkastellut myös useissa moniosaisiksi rönsyilleissä elokuvissaan tyyppiesimerkkinä Dog Star Manin jälkeen valmistunut 30-osainen, alkujaan 8 mm:n filmille kuvattu Songs (1964-69). Kolmas, laajan sarjamuodon saanut kokonaisuus Brakhagen 1960-luvun tuotannossa on yritys oman henkilöhistorian tarkempaan tarkasteluun elokuvasarjassa Scenes From Under Childhood (1967-70).

Ezra Poundin "hengessä" toteutettu Songs on sarja "asenne-elokuvia" (päiväkirja-, muotokuva- ja muistikirja-elokuvien joukossa); kukin yksittäinen laulu pyrkii tuomaan näkyville tietyn elämänasenteen. Arkielämän yksinkertaisia asioita on taltioitu filmille hyvin pelkistetysti. Songs-elokuvissa kiteytyvät amerikkalaisen riippumattoman elokuvan peruselementit: välittömyys, kosketus ympäröivään arkitodellisuuteen, vapaus, spontaanisuus ja suoruus eli sellaiset ominaisuudet, joiden ansiosta video sittemmin otti paikkansa juuri vastaavanlaisen "asenne-elokuvan" välineenä.

1970-luvun alussa useat kokeellisen elokuvan veteraanit oleskelivat Pittsburghin teollisuuskaupungissa. Ruoste, metalli ja palava rauta ilmeisesti vetivät tekijöiden visuaalista intohimoa puoleensa. Tai kenties he halusivat vain kokea ympäristön, josta tuolloin maineensa kukkuloilla vaeltanut Andy Warhol oli kotoisin. Toisaalta rappeutuva terästeollisuuteen erikoistunut kaupunki tarjosi jyrkän kontrastin 
Brakhagelle niin läheisen maaseudun, luonnon ja vuoristomaiseman vastakohtana. Tuolta ajalta on peräisin elokuva The Act of Seeing with One's Own Eyes (1971), joka on kliinisen tarkkaa taltiointia siitä, mitä tapahtuu ruumiinavauksissa. Samalla se osoittaa, ettei kokeellinen asenne merkinnyt Brakhagelle pelkästään abstrakteja muotokokeiluja, vaan saattoi toteutua myös varsin "perinteisin" elokuvallisin keinoin. Mutta edelleen, kuten nimestä voi päätellä, dokumentin keskeinen teema on kysymys näkemisen luonteesta. Kertomansa mukaan suurin haaste itse elokuvan toteutuksessa ei kuitenkaan liittynyt näkö- vaan hajuaistiin; kesti viikon ennen kuin patologian huoneiden hajuun tottui (ks. Ganguly 2017, 116-119).

Olennainen osa Brakhagen myöhempää tuotantoa - noin 1980-luvun puolivälistä alkaen aina tekijän kuolemaan saakka 2000-luvun alussa - on paluuta abstraktiin ilmaisuun. Tämä tapahtuu lopulta nimenomaan muodossa, jossa kameraakaan ei enää käytetä vaan elokuvat tehdään maalaamalla värikuvioita suoraan filminauhan pintaan. Sitney (2015) nimittää tätä vaihetta Brakhagen tuotannossa tekijän itsensä keksimällä termillä "kuvagnostiset elokuvat" (imagnostic). Yhtäältä paluun tällaiseen "käsityöläisyyteen" voi toki omalta osaltaan tulkita yrityksenä herätellä taas henkiin romanttisen taiteilijakuvan ihanteellisuutta. Toisaalta tällaisen käsin tehdyn työn tulokset voi nähdä ja kuulla korostetulla tavalla materiaalisena ilmaisuna, jossa etsitään jonkinlaista musiikin, kuvataiteen ja runouden toisiinsa yhdistävää erityistä elokuvallisuutta. Elokuvallinen materiaalisuus tarkoittaa tässä nimenomaan perinteistä selluloidifilmiä. Sen moninaista työstämistä silmällä pitäen Brakhage jopa julkaisi eräänlaisen kokeellisen tekijän opaskirjan nimellä The Moving Picture Giving and Taking Book (1971).

Brakhagen elokuvat ovat kokeita siitä, millaiselta erityisiin aineksiinsa - valoon, väriin ja liikkeeseen - tukeutuva elokuvallinen ilmaisu näyttää ja kuulostaa. Juuri tässä merkityksessä hänen tuotantoaan on mahdollista tarkastella elimellisenä osana kokeellisen taiteen perinnettä: se tarttuu työkaluun (elokuva erilaisine aineineen ja laitteineen) tutkiakseen aistimellisen kokemusmaailman jotakin ulottuvuutta. Brakhagen tapauksessa tämä tarkoittaa eritoten ihmissilmän kykyä ja kyvyttömyyttä nähdä ja kokea liikettä. Asetelma ei kuitenkaan pelkisty psykofyysiseksi ongelmaksi vaan kantaa mukanaan aina myös oman historiallisen myyttisyytensä. Sen kirjaimellinen "merkkipaalu" voisi olla Dog Star Man -elokuvan maailmanpuu. Yksi sen viimeisistä, nimetyistä tarkasteluista on elokuva Yggdrasill: Whose Roots are Stars in the Human Mind (1997). Sen kuvitellun oksiston läpi suodattuvan valon aikaan saamia heijastuksia saattaisi pitää Brakhagen kaikkien elokuvien "alkuaineena".

\section{Lähdeluettelo}

\section{Brakhage-teokset}

Brakhage, Stan (2017) Metaphors on Vision. New York: Anthology of Film Archives \& Light Industry (alk. 1963).

— (2003) Telling Time: Essays of a Visionary Filmmaker. New York: Documentext.

- (2001) Essential Brakhage: selected writings on filmmaking. Toim. Bruce R. McPherson. New York: Documentext.

— (1989) Film at Wit's End. Eight Avant-Garde Filmmakers. New York: McPherson \& Company.

— (1982) Brakhage Scrapbook. Collected Writings 1964-1980. Toim. Robert A. Haller. New York: Documentext.

— (1979) Film Biographies. 2. painos. Berkeley: Turtle Island (alk. 1977). 


\section{Muu kirjallisuus}

Deleuze, Gilles (1986) Cinema 1: The Movement-Image. Käänt. Hugh Tomlinson ja Barbara Habberjam. Minneapolis: University of Minnesota Press (Cinéma 1. L'Image-Mouvement, 1983).

Deleuze, Gilles (1989) Cinema 2: The Time-Image. Käänt. Hugh Tomlinson ja Robert Galeta. London: The Athlone Press (Cinéma 2. L'Image-Temps, 1985).

Dwoskin, Stephen (1985) Film Is. The international free cinema. 2. painos. New York: The Overlook Press (alk. 1975).

Ganguly, Suranjan (toim.) (2017) Stan Brakhage Interviews. Jackson: University of Mississippi Press.

James, David E. (2005) Stan Brakhage: Filmmaker. Wide Angle Books. Philadelphia: Temple University Press.

James, David E. (1989) Allegories of Cinema: American Film in the Sixties. Princeton: Princeton University Press.

Osterweil, Ara (2014) Flesh Cinema: The corporeal turn in American avant-garde film. Manchester: Manchester University Press.

Sitney, P. Adams (2015) The Cinema of Poetry. Oxford, New York: Oxford University Press.

Sitney, P. Adams (1979) Visionary Film. The American Avant-Garde 1943-1978. 2. painos. Oxford: Oxford University Press (alk. 1974).

Wees, William C. (1992) Light Moving in Time. Studies in the Visual Aesthetics of Avant-Garde Film. Berkeley, Los Angeles, Oxford: University of California Press.

Wodening (Brakhage), Jane (2015) Brakhage's Childhood. New York: Granary Books.

Youngblood, Gene (1970) Expanded Cinema. New York: E.P. Dutton \& Co., Inc. 